means improving the crop by choosing wheat that is immune from the effects of incidental causes which are part of the natural order and used to be instrumental in depressing the market yield. Moreover, when wheat was cheap there was a disposition only to sow it in the most favourable land, to withdraw the rest from wheat-cultivation, and thus to raise artificially the average yield per acre.

Considering all the circumstances, even as they were in 1906 , it is surprising that any suggestion of law should come out of the figures at all. Improved know. ledge among farmers may easily now have introduced variations which will form a systematic error in the comparison of facts with the calculations of either "theory"; consequently the investigation means rather more than comparing figures. The mere repetition of the process that was good enough for 1904 may be illusory in 1917 , for causes which were not inherent in the original figures.

Napier Shaw.

\section{A Frost Thistle: A Beautiful Effect of Freezing.}

THE frost flower here photographed was entirely the result of a chance experiment, but it was so beautiful that it would be well worth repetition and detailed study.

So far as I can see, the sole factors necessary for the production of such an effect are a small amount of garden mould left standing in a little water (about

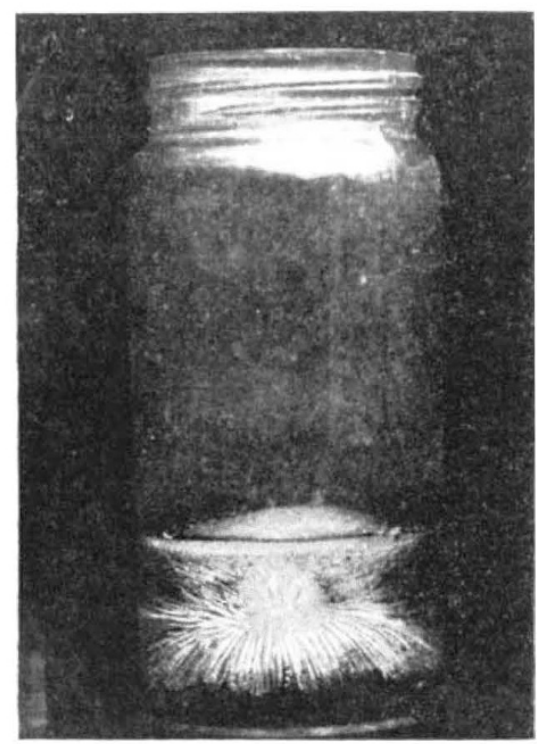

an inch in depth) in a small glass jar, and frosty weather. In this particular case the vessel was left out of doors on a window-sill during a recent frosty night in a state of tranquillity save for the occasional shakings caused by vehicles passing over the bridge below.

In the morning the water was frozen solid; the glass was intact, the ice having expanded upwards, doming the surface. Within the ice cylinder was a wonderfully perfect representation of a thistle flower, most delicately fashioned in gleaming threads of silvery whiteness and of exquisite beauty, all emanating from a fluffy-looking, opaque, central, domed nucleus.

In reality the threads were fine curved threads of gas (? air) radiating through the clear ice. As shown in the figure, those below curved downwards, those above upwards, for all the world like lines of force round a magnetic pole, but demonstrated by capillary No. 2463 , VOL. 98] tubes in ice. On closer examination I was, I believe, able to discover another essential feature in the phenomenon in the form of tiny specks of mud, one at the peripheral end of each gas-tube.

I submit the following explanation of the frost thistle.

It must be assumed that as freezing proceeds from without inwards, the gas-tubes also grew centripetally. The tiny particles of earth we believe to have determined the points of origin of minute gas bubbles. When the first shell of ice was formed, these bubbles would naturally, by the expansion of the ice, tend to be squeezed and compelled to elongate, and then to move in the direction of least resistance-i.e. inwards and towards the centre of the vessel. In other words, these silvery threads, curving, as they do, upwards from the bottom and downwards from the top, are graphs which indicate the progress of the congelation.

When the congelation had reached to about one-third of the radial distance to the centre, some change appears to have occurred, for the central ice-mass was no longer clear, but of a milky opaqueness, within which the gas-tubes could be no longer followed by the eye. This we attribute to the sudden solidification of a confined residual volume of liquid of enhanced salinity, which, at the moment of its change of state yielded up its dissolved gases in countless bubbles of the minutest size. These, probably uniformly distributed throughout the central ice, produced its cloudiness.

May I add that this example of natural magic grew within a few yards of the site of Roger Bacon's study on Folly Bridge at Oxford? R. T. Gunther.

\section{NATIONAL RECONSTRUCTION.}

I $T$ is not too much to say that of all the subjects which claim careful consideration at the present time of discussion as to Imperial reconstruction, none is more important than education. It is true that the consequences of any change for the better or worse in educational matters will affect more directly the next generation than the present, but the clarification of men's minds and the settlement of a course of action in this direction are urgently desirable. For it is evident that opinion is still much divided as to the aims which ought to be kept in view, and until such divisions are practically healed the present wasteful conflict will go on.

The discussion which has been carried on during so many years by the partisans of classical studies on one hand, and the supporters of science on the other, is an indication that there is still much misunderstanding and exaggeration on both sides. The extremists on one side contend that Greek is an essential element in a liberal education, and talk of physical science as "gross materialism," while some of the extreme opponents of classical studies are not content with dropping Latin and Greek, but would turn schoolboys into technical chemists. It is to be hoped that the people with more moderate views, who fortunately seem to form the majority, will arrive before long at a generally acceptable compromise whereby the interests of a truly liberal education may be secured.

The advocates of the classical system have shown in recent utterances a moderation which 
may be taken as indicating a politic submission to the force of that part of public opinion which is against them. An example occurred at the meeting of the Hellenic Society on November I4, Dr. Walter Leaf, president, being in the chair. The president opened the proceedings with some remarks about compulsory Greek in the entrance examinations at Oxford and Cambridge for which he would receive the cordial thanks of any friends of physical science who may have listened to him. As he justly pointed out, the study of Greek must stand or fall on its own merits, and he denounced the retention of Greek as a compulsory subject in terms as vigorous as could be desired both by those who care nothing for classical learning and by those who have the interests of Hellenic studies at heart. For there can be no doubt that the number of young people who enjoy the gifts which enable them to push on beyond the difficulties of the language itself, so as to be in a position to imbibe and to enjoy something of the beauty of Greek poetry, drama, and philosophy, is, and must always remain, relatively small; while the forcing of hundreds of young men to undergo the drudgery of getting up an imperfect knowledge of Greek grammar and some small portion of a Greek author is deliberately to create a crowd of people who in after life hate and despise the system which has compelled them to waste so much time.

Dr. Leaf made a mistake in his reference to what he described as the present tendency to exalt materialistic science. Everyone knows that the circumstances of the time compel a concentration of attention on inventions which have arisen out of scientific discovery, and to the unthinking the production of dyes and explosives, of big guns and aeroplanes, may appear to be the chief aim and purpose of scientific research. But this is not all that science has to offer, nor is it the purpose towards which instruction in scientific principles, methods, and results as an element in a liberal education should be directed. Such products of scientific activity belong mainly to the technical school and the workshop, and though a good deal of illumination for the mind may be derived from a study of such things, the primary purpose in the use of physical science in education is in training the powers of observation, the application of the inductive method to the results and the acquisition of such a knowledge of the external world as is necessary to the intellectual life of the modern civilised man. Surely no man brought up under the classical system at school and university can pretend that he is indifferent to the discoveries in electricity, chemistry, and biology in the last half-century. Present knowledge about the constitution of the chemical elements and the application of the principles of evolution have so changed all ideas about the world in which we live and the nature of man himself that such changes can be ignored by no one who claims to be called an educated man.

It may be asked whether it would not be an advantage even to the classical scholar that he No. 2463 , voL. 98$]$ should be in a position not only to learn from the newspapers that discoveries have been made, but also to understand something of the nature of the evidence on which they are assumed to be established. It appears, however, that there are people who still think otherwise, and, as governors of schools and universities or Civil Service Commissioners, do not hesitate to place all kinds of obstacles in the way of the new learning and to draw or drive away from the fields of science many of the best brains in the country. Protests have already been raised over and over again at meetings of the British Association, at the British Science Guild, in addresses by presidents of the Royal Society, and at the gathering organised by the Neglect of Science Committee in May last. A fresh and vigorous denunciation of this kind of obstruction was uttered by Prof. Soddy in November last at a meeting of the University Scientific Society at Aberdeen. His subject was "The Future of Science and What Bars the Way," and he began by addressing himself to the consideration of the latter question because he believes that active opposition has still to be overcome before science can take its rightful place in the Scottisi universities. He repeats with emphasis what has been asserted already often enough, namely, that some of the older institutions have lost whatever capacity they may once have had for intellectual leadership, and by the inherent qualities of their system they perpetuate a type of man who is out of harmony with the present age, who remains in a world of medieval obscurantism, and is an 'obstacle in the way of future national reconstruction. A claim is set up for the older studies: to an elevating spiritual influence which the present state of the world shows to have failed. In the meantime science has put at the disposal of man physical powers which, in the hands of the barbarian uninfluenced by the humanist, threaten to wreck the world.

The conservatism and exclusiveness of which Prof. Soddy complains are not confined to the Scottish universities. They pervade the schools throughout the' kingdom, dominated as most of them are by the classical stronghold of Oxford; and in the public service of the country the statesman, the headmaster, and the divine remain largely blind and deaf to the signs and warnings of the time. They claim not merely to preserve a sanctuary for the memory of departed glories, but their decadent humanism continues to monopolise the avenues to preferment, to positions of influence, opportunity, and honour.

But what will be likely in the address to attract most attention in Aberdeen, and perhaps elsewhere, is the charge which is brought against the University Court of financial jugglery to the disadvantage of science and medicine. Mr. Carnegie in rgor gave two millions sterling to the Scottish universities for the purposes of scientific study and research as well as payment of the fees of deserving students. Prof. Soddy asserts that owing to the form in which the accounts are pub- 
lished, it becomes possible to divert the money to a large extent from the objects for which it was intended, and that this operation has been applied to the departments of chemistry and geology. Obviously these are matters which will have to be looked into.

In the conflict which is going on there can be no doubt that, assisted as it is by the prominence of the many practical problems, of which the dyes are the most notorious example, science will utimately win the day. The purely classical people will have to give way, and there is evidence that all over the country some progress has been made in the quality of the science teaching in the schools. It is to be hoped that in the triumph of the practical the interests of the liberal will be duly safeguarded. We can no more afford to let go ancient literature and history than modern physics and chemistry. All that the representatives of science ask for is that the new may be admitted to an equal place alongside the old, where both may stand in mutual honour and esteem.

The indifference to the value of science appears to be almost attributable to a natural conservatism inherent in the British character. It certainly has pervaded a large part of the business world up to quite recent times, when the pressure of war-work has served as a wholesome stimulant. The newspapers are full of discussions as to what is to happen when the war ceases, but for the most part they have rather a specialist character. A series of articles appeared in the Times of July and August last in which "The Elements of Reconstruction," in reference to the Empire, were discussed in an unusually broad and thoughtful spirit. They have been reprinted with an introduction by Lord Milner, ${ }^{1}$ and both articles and introduction deserve to be read carefully and digested by all thoughtful men. The keynote of the whole may be said to be co-operation. This means that, in the view of the writers, the methods of business will have to be changed completely; there must be among manufacturers mutual support and confidence instead of suspicion and rivalry; and in the interests of the State many small businesses in competition with one another must be united. There must be national scientific education, and the men who control the industries must be fully qualified by education, liberal as well as special, not only to understand fully their own processes, but to deal in an enlightened spirit with all the problems connected with labour.

Whether the doctrine that food production, fuel, and transport are not to be left under the control of private ownership, but transferred to public administration, will within our time be put into practical operation is a question. The author's opinion is that such a development can be realised, not by the Socialist panacea of "expropriation," but "by amalgamation, by co-ordination and cooperation, by bringing the State into partnership, and an increasing partnership, in the big businesses that result from these amalgamations, by develop-

$$
1 \text { Nisbet and } \mathrm{Co}, \mathrm{I} \cdot \mathrm{d} \text {. Is. net. }
$$

No. 2463 , VOL. 98] ing the crude beginnings of the 'controlled establishment,' by the quid pro quo of profit-sharing and control in the national interest in exchange for the national credit and a helpful tariff."

Labour and trade-unions provide another text which needs much careful thought. A temper must be cultivated free from class hostility and the use of aggressive phraseology. The war has doubtless done some little to clear away jealousy and suspicion between employer and employed, to so large an extent the fruit of traditional misunderstandings. "The efficacy of ignorance," to use an expression of Dr. Johnson's, has been tried long enough, and that is why at the outset the prime importance of education was assumed. It is interesting to notice that in the opinion of the authors of "Eclipse or Empire?" reviewed in NATURE of November 9, the falling-off which they claim to have observed in inventions is due to our defective system of education. Here there are evidently two distinct propositions, of which the former is open to question. If the former is established, there will not be much difficulty in accepting the latter.

The lack of clear thinking is one of the evil influences of the past, and as labour continues to make its voice heard, sometimes above other voices, it is imperatively necessary that the broadening of the higher education in school and university shall be accompanied by a lengthening and deepening of the course in the elementary schools.

\section{ACCESSORY FACTORS, OR "VITAMINES," IN DIET.}

$\mathrm{IT}^{\mathrm{T}}$ was known to Captain Cook that fresh food, especially green vegetables, contained something which was absent from the preserved food used by him in his voyages, but was necessary to maintain health. Stepp showed, a few years ago, that bread and milk, if extracted with alcohol, did not suffice for the growth of rats, but that addition of the residue from the alcohol extract restored the adequacy of the diet. Hopkins then found that rats are unable to grow on a diet, otherwise complete, composed only of pure protein, fat, carbohydrate and salts, although this diet can be rendered perfectly adequate by the addition of a minute amount of milk. Further research by Osborne and Mendel and others in the United States confirmed these results.

There are, therefore, certain necessary constituents of food the presence of which is not obvious to chemical examination, owing to the very small amount contained. For these substances the name "vitamines" was suggested by Funk, on the basis of chemical work which was afterwards found by him to be incorrect. Unfortunately the word has come into use. Since we are, as yet, ignorant of their chemical nature, which is probably of several kinds, it is preferable to use the longer name, "accessory factors."

An interesting accrunt of some of the aspects of the problem, especially those of practical interest, 